Bangladesh J. Zool. 49(1): 91-103, 2021

ISSN: 0304-9027

eISSN: 2408-8455

\title{
LENGTH-WEIGHT RELATIONSHIPS AND RELATIVE CONDITION FACTOR OF THE MULLET, RHINOMUGIL CORSULA (HAMILTON, 1822) IN THE SITAKUNDA COAST OF THE BAY OF BENGAL, BANGLADESH
}

\author{
Syeda Ismat Ara ${ }^{1}$, Mohammad Ali Azadi², Munira Nasiruddin and Aftab Hossain ${ }^{1 *}$ \\ Department of Zoology, University of Chittagong, Chattagram 4331, Bangladesh
}

\begin{abstract}
This study deals with the length-weight relationship and relative condition factor $(\mathrm{Kn})$ of 2480 specimens of Rhinomugil corsula (Hamilton, 1822), ranging from $3.5 \mathrm{~cm}$ to $29.5 \mathrm{~cm}$ total length and $0.40 \mathrm{~g}$ to $235.34 \mathrm{~g}$ weight, sampled monthly for two years period from March 2016 to February 2018 from the Sitakunda Coast of the Bay of Bengal, Bangladesh. Arithmetic form of equations for length (TL) and weight (W) of fish showed curvilinear relationships in male: $\mathrm{W}=0.0081 \mathrm{TL}^{3.016}$, female: $\mathrm{W}=0.0083 \mathrm{TL}^{3.058}$ and combined sex: $\mathrm{W}=0.0076 \mathrm{TL}^{3.052}$, while logarithmic scale showed linear relationships in male: $\mathrm{LogW}=-$ 2.122+3.016LogTL, female: $\log W=-2.09+3.058 \mathrm{TL}$ and combined sex: LogW=$2.121+3.052 \mathrm{TL}$. In all the cases the coefficient of correlations between length and weight were positive and highly significant $(\mathrm{P}<0.01)$. The regression coefficient ' $\mathrm{b}$ ' values were found to be $3.01 \pm 0.11,3.06 \pm 0.12$ and $3.05 \pm 0.12$ for male, female and combined sexes, respectively for two years period together. When ' $t$ ' test was done, the growth was found to be isometric in case of male and combined sex and positive allometric in case of female. The relative condition factor $(\mathrm{Kn})$ varied from 1.0003$1.009,1.001-1.008$ and 1.001-1.008, respectively, for male, female and combined sex in 2016-17, whereas 1.001-1.007, 1.003-1.006 and 0.992-1.008 respectively in 201718. The Kn values were always around ' 1 ' or a little bit more than ' 1 ' for length groups as well as monthly, indicating the excellent growth and robustness of fish due to favorable environmental condition prevailing in the habitat of the fish, in the Sitakunda coast of the Bay of Bengal.
\end{abstract}

Key words: Length-weight relationship, relative condition factor, Rhinomugil corsula, Sitakunda coast, Bangladesh

\section{INTRODUCTION}

Rhinomugil corsula is a Mullet fish, belongs to the family Mugillidae, commonly known as Corsula Mullet, and locally known as Bata, Khalla or Khorsula found in the rivers and estuaries of southern Asia, in Bangladesh, India, Nepal and Myanmar (Froese and Pauly 2018). The fish is very hardy and

*Author for corresponding: <aftab_zool@yahoo.com>, 2International Islamic University Chittagong 4318, Bangladesh

(C2021 Zoological Society of Bangladesh DOI: https://doi.org/10.3329/bjz.v49i1.53685 
can tolerate a wide range of salinity and temperature, hence, could be suitable for culture in intertidal ponds of coastal zone. The analysis of the mathematical relationship between the length and weight of a fish species is very much necessary in the study of biology, management, and population dynamics of fish species; as the study of these parameters solve a number of problems related to the biology of fish such as variation in growth, size at first maturity, gonad development, and breeding season (LeCren 1951, Ricker 1975 and Chatterji et al. 1977). Extensive works on length-weight relationship along with relative condition factor and aspects of biology of different fish species have been done in the different parts of the world including India and Bangladesh (LeCren 1951, Doha and Dewan 1967, Shafi and Quddus 1975a,b, Das 1977, Azadi et al. 1988, Azadi and Nasiruddin 1990, Azadi et al. 1992, Azadi and Naser 1996, Çelik and Torcu 2000, Kar and Barbhuiya 2000, Mamun and Azadi 2004, Azadi and Rahman 2007, Azadi and Ullah 2008, Erguden et al. 2009, Azadi and Arshad-ul-Alam 2011, Parvin et al. 2011, Ranjini and Nandan 2011, Chu et al. 2012, Akter and Akter 2013, Zubia et al 2014, Sharma 2015, Ali et al. 2016, Moslen and Miebaka 2017, Türker and Bal 2018, Pramanick et al. 2017 and Das et al. 2018). Some works on the $R$. corsula from freshwater area have also been done in India (Ranganathan and Natarajan 1969, Suganun and Vinci 1981, Fatima 1991, and Fatima and Khan 1993). But no published work was found on the length-weight relationship and relative condition factor of this commercially important mullet, Rhinimugul corsula from the southeastern coast of Bangladesh. Hence, the study on length-weight relationship and relative condition factor of $R$. corsula was undertaken in the present investigation. This study might help to understand the growth pattern and wellbeing of the fish and health condition of the habitat in the Sitakunda coast of the Bay of Bengal which is very much needed in fisheries management.

\section{MATERIAL AND METHODS}

Collection of samples: Experimental fishes were collected from the three fish landing stations namely (1) Sitakunda bazar fish landing station $\left(22^{\circ} 37^{\prime} 12^{\prime \prime} \mathrm{N}\right.$, $\left.91^{\circ} 46^{\prime} 4^{\prime \prime} \mathrm{E}\right)$ (2) Kumira fish landing station $\left(22^{\circ} 30^{\prime} 33^{\prime \prime} \mathrm{N}, 91^{\circ} 41^{\prime} 56^{\prime \prime} \mathrm{E}\right)$ and (3) Bhatiari fishing village $\left(22^{\circ} 25^{\prime} 39^{\prime \prime} \mathrm{N}, 91^{\circ} 44^{\prime} 17^{\prime \prime} \mathrm{E}\right)$, and sometimes directly from fishermen catch in the Sitakunda coast. After collection, the fish samples were brought to the laboratory of the Department of Zoology, University of Chittagong. Lengths were measured to the nearest centimeter $(\mathrm{cm})$ and weight up to the nearest gram $(\mathrm{g})$. The fishes were grouped according to sex and those fish which were too small to identify the sex were considered as combined sex. Samples were collected monthly, thus a total of 2480 specimens of Rhinomugil corsula were 
collected, where 854 were males, 1482 were females and 144 were unsexed due to small size. Fish total length and weight ranged from $3.3 \mathrm{~cm}$ to $29.5 \mathrm{~cm}$ and $0.4 \mathrm{~g}$ to $235.34 \mathrm{~g}$, respectively. Of total 2480 fishes, 1231 were collected and examined during first year, from March 2016 to February 2017 and the remaining 1249 during second year, from March 2017 to February 2018. The L-W data of male and female fishes were used for the study of length-weight relationship separately and also for combined sexes for each year and also for two years together. Sexes of undetermined fishes below $7 \mathrm{~cm}$ length were treated under combined sexes.

Length-weight relationship: The length-weight relationships were calculated following the non-linear formula of LeCren (1951): $\mathrm{W}=\mathrm{aL}^{\mathrm{b}}$, Where $\mathrm{W}=$ total body weight $(\mathrm{g}), \mathrm{L}=$ total body length $(\mathrm{cm}), \mathrm{a}=$ intercept / constant, $\mathrm{b}=$ exponent. This relationship was also expressed in the logarithmic transformation giving a straight line relationship, $\log \mathrm{W}=\log \mathrm{a}+\mathrm{b} \log \mathrm{L}$. This equation is same to $\mathrm{Y}=\mathrm{a}$ $+\mathrm{bX}$, where $\log \mathrm{W}=$ dependent variable $(\mathrm{Y}), \log \mathrm{L}=$ independent variable $(\mathrm{X}), \mathrm{b}=$ regression coefficient, $\mathrm{a}=$ intercept. To get an idea of the relationships (linear, curvilinear or non-linear) between the length and weight, a scattered diagram was drawn, after that arithmetic (curvilinear) and logarithmic (linear) graphs were fitted. The t-test was employed to confirm whether regression coefficient ' $b$ ' differed significantly from the cube law. All ' $b$ ' values were subjected to t-test, as

suggested by Johnson and Ndimele (2010) using the following formula: $t=\frac{(b-3)}{\text { S.E.(b) }}$, where S.E. $=$ Standard error of regression coefficient ' $b$ ' and S.E. $=s \sqrt{n}$, where, $s=$ standard deviotion, $\mathrm{n}=$ number of sample. All statistical analyses were done using the software 'SPSS' (version-16) and graphs and diagrams for data presentation were produced using MS Excel (version-2007).

Relative condition factor: To see the effect on body condition due to different length groups and seasons, monthly and length group wise relative condition factor' $(K n)$ was calculated for male and female sexes separately and also for both the sexes combined, following LeCren (1951):

$\mathrm{Kn}=\frac{\mathrm{W}}{\overline{\mathrm{W}}}$, where $\mathrm{Kn}=$ relative condition factor, $\mathrm{W}=$ observed weight, and $\overline{\mathrm{W}}$ =calculated weight

\section{RESULTS AND DISCUSSION}

Length-weight relationship: The length and weight of the studied fishes were significantly correlated with each other in all the months $(\mathrm{P}<0.01)$ and the values of coefficient of correlation $(\mathrm{r})$ ranged between 0.990 and 0.998 for males; 0.991 and 0.999 for females, and 0.990 and 0.998 for combined sex. 
Curvilinear and linear relationship was observed in arithmetic and logarithmic expression of length-weight relationship respectively, for male, female and combined sex in both first (2016-17) and second year (2017-18) (Table 1) as well as in the combined data of both the years (2016-18) (Figs. 1 and 2). Similar relationships between length and weight of $R$. corsula but collected from freshwater reservoir and rivers were also recorded by many authors (Mortuza and Rahman (2006), Fatima (1991), Suganun and Vinci (1981), Ranganathan and Natarajan (1969) in different parts of the world. The rate of change of weight relative to length was slightly different for males than that of the females in 24 months of the study. The regression coefficients (b) were $3.01 \pm 0.11,3.06 \pm 0.12$ and $3.05 \pm 0.12$, respectively, for males, females and combined sex, indicated that the growth of male was slightly slower than that of the females. The growth rate of both sexes was slightly more than that of the cube of length as the 'b' values for males and females were greater than 3 . The 'b' values varied from 2.834 to $3.17,2.837$ to 3.216 , and 2.856 to 3.193 , respectively, for male, female and combined sex in 2016-17 (first year); whereas 2.855 to $3.223,2.957$ to 3.322 , and 2.905 to 3.216, respectively, for male, female and combined sex in 2017-18 (second year). Different authors reported different ranges of 'b' value for different fishes. Hile (1936) and Martin (1949) reported the exponent varying form 2.5-4.0 for fishes, whereas Raja (1967) found a range of 2.0-5.4 in marine teleosts. Ranganathan and Natarajan (1969) reported an overall 'b' value 3.002 and 3.175 for $R$. corsula from Sathnur Reservoir and Krisnagiri Reservoir, India. Carlander (1977) stated that 'b' value will remain within 2.5 to 3.5 if the data are real and calculated for large number of fish randomly. According to Carlander $(1977)<2.5$ or $>3.5$ values of ' $b$ ' indicate the small numbers of data or data were collected erroneously. Suganan and Vinci (1981) reported an overall 'b' value of 2.958 at Nagarjunasagar Reservoir of India. Fatima (1991) reported the 'b' values of male, female and combined sex of $R$. corsula to be 2.767, 2.987 and 2.986, respectively from the River Yamuna, India; whereas, Mortuza and Rahman (2006) reported the 'b' values to be 2.941, 3.008 and 2.984 for $R$. corsula from Padma River in Rajshahi, Bangladesh. The theoretical value of regression coefficient (b) in length-weight relationship is reported as 3 , when the body form of fish remains constant (hypothetical ideal fish) at different length, i.e., growth is isometric and the weight will be proportional to the cube of length if the fish does not change form or density as it grows (Allen 1938). But in natural condition most of the fishes do not follow the 'cube law' as the specific gravity, body shape or body outline of the fish changes in different phase of growth and season (Rousenfell and Everhart 1953). If the value of 'b' deviates from the ideal value (3) then it is called allometric growth, thinner and heavier fishes have the ' $\mathrm{b}$ ' value below and 
above 3, accordingly called negative and positive allometric growth respectively (Grover and Juliano 1976, King 2007). The variation in the estimates of the coefficient ' $b$ ' from expected value of ' 3 ' (cube law) was tested by 't-test'. No significant difference were found between the $b$ value of male $(t=0.482, d f=23$, $\mathrm{P}>0.01)$ and combined sex $(\mathrm{t}=2.216, \mathrm{df}=47, \mathrm{P}>0.01)$ with cube law but for female significant difference $(t=2.623, d f=47, P<0.01)$ was observed. Hence, the growth of male and combined sex was considered as isometric, whereas, that of female was found to be positive allometric, indicating the good environmental condition of the fish habitat at the Sitakunda coast. In all other previous studies (Mortuza and Rahman 2006, Fatima 1991, Suganan and Vinci 1981, Ranganathan and Natarajan 1961) where $R$. corsula were collected either from large reservoir or from rivers, the exponent was less than the present study suggesting that the estuarine habitat of the coast of Bay of Bengal in Sitakunda provided a better environment for $R$. corsula. Sex related difference of the exponent ' $\mathrm{b}$ ' was very much evident in the present study - the values of ' $\mathrm{b}$ ' for females were greater than those of the males. Differences in gonad development or other physiological changed between sex of fishes may influence in sex related difference in weight of a given length (Fatima 1991). In the present study female fishes had higher ' $b$ ' values during the breading season of the fish (June to October) agreed the findings of Fatima (1991).

Table 1. Length (TL)-Weight (W) relationships of male, female and combined sex of $R$. corsula in arithmetic and logarithmic scale at Sitakunda coast during two years study period (2016-17 and 2017-18)

\begin{tabular}{|c|c|c|c|c|}
\hline Year & Sex & Arithmetic & Logarithmic & $\mathbf{S E}(\mathbf{b}) \pm$ \\
\hline \multirow{3}{*}{$\begin{array}{c}2016- \\
17\end{array}$} & Male & $\mathrm{W}=0.0081 \mathrm{TL}^{3.01}$ & $\operatorname{LogW}=-2.093+3.01 \log T L$ & 0.0332 \\
\hline & Female & $\mathrm{W}=0.0076 \mathrm{TL}^{3.05}$ & $\operatorname{LogW}=-2.119+3.051 \mathrm{Log} T L$ & 0.037 \\
\hline & Combined & $\mathrm{W}=0.0084 \mathrm{TL}^{3.007}$ & $\operatorname{LogW}=-2.075+3.007 \log T L$ & 0.033 \\
\hline \multirow{3}{*}{$\begin{array}{c}2017- \\
18\end{array}$} & Male & $\mathrm{W}=0.0081 \mathrm{TL}^{3.019}$ & LogW $=-2.094+3.019 \log T L$ & 0.033 \\
\hline & Female & $\mathrm{W}=0.0076 \mathrm{TL}^{3.066}$ & $\mathrm{LogW}=-2.121+3.066 \mathrm{LogTL}$ & 0.033 \\
\hline & Combined & $\mathrm{W}=0.0086 \mathrm{TL}^{3.013}$ & $\mathrm{LogW}=-2.068+3.013 \operatorname{LogTL}$ & 0.026 \\
\hline \multirow{3}{*}{$\begin{array}{c}2016- \\
18\end{array}$} & Male & $\mathrm{W}=0.0081 \mathrm{TL}^{3.016}$ & $\operatorname{LogW}=-2.122+3.016 \log T L$ & 0.023 \\
\hline & Female & $\mathrm{W}=0.0083 T \mathrm{TL}^{3.058}$ & $\operatorname{LogW}=-2.09+3.058 \log T L$ & 0.025 \\
\hline & Combined & $\mathrm{W}=0.0076 \mathrm{TL}^{3.052}$ & $\log \mathrm{W}=-2.121+3.052 \mathrm{TL}$ & 0.020 \\
\hline
\end{tabular}

Relative Condition factor: The ranges of relative condition factor $(\mathrm{Kn})$ were 1.0003-1.009, 1.001-1.008 and 1.001-1.008, respectively, for male, female and combined sex during 2016-17, whereas 1.001-1.007, 1.003-1.006 and 0.992-1.008 respectively during 2017-18. Yearly, the highest Kn value was found in males of 2016-17 and combined sex of 2017-18, whereas, the lowest Kn value was obtained in females of 2016-17, and males and females of 2017-18 (Table 1). The relative condition factor $(\mathrm{Kn})$ of a fish can be influenced to varying extent by several factors. 
Fluctuations of ' $\mathrm{Kn}$ ' values might occur due to factors such as condition of environment, seasonality, abundance of food, maturity stages, size range, ages, sex, increase or decrease in feeding activities, amounts of accumulated fats and effect of parasites (Pervin et al. 2011, Zubia et al. 2014). But majority of the authors reported that monthly fluctuations in 'Kn' are closely related to the sexual cycle of the fish, and the fluctuations in the ' $\mathrm{Kn}$ ' values are due to fluctuations in the weight of gonads before and after the spawning (LeCren 1951, Morrow 1951 and Sarojini 1957). However, other workers have suggested the feeding rhythm of fish is more closely related to monthly fluctuations of $\mathrm{Kn}$ and these fluctuations are independent of reproductive cycle (Hile 1948, Qasim 1957, Bal and Jones 1960). Generally, the gonad related weight gain during pre-spawning period cause the increase in ' $\mathrm{Kn}$ ' values and when the ovary of fishes become spent, consequently the weight and physical condition of fish decline, hence the 'Kn' value falls sharply.

Table 2. Relative condition factors of male, female and combined sex of $R$. corsula during the study period

\begin{tabular}{llcc}
\hline \multirow{2}{*}{ Year } & \multicolumn{2}{c}{$\begin{array}{c}\text { Type and Sample } \\
\text { numbers }\end{array}$} & $\begin{array}{c}\text { Relative condition } \\
\text { factor }\end{array}$ \\
\cline { 2 - 4 } & Type & Number & Mean \pm SD \\
\hline \multirow{2}{*}{$2016-17$} & Male & 428 & $1.007 \pm 0.10$ \\
& Female & 741 & $1.005 \pm 0.11$ \\
& Combined & 1231 & $1.006 \pm 0.11$ \\
$2017-18$ & Male & 426 & $1.005 \pm 0.09$ \\
& Female & 741 & $1.005 \pm 0.11$ \\
& Combined & 1249 & $1.007 \pm 0.11$ \\
\hline
\end{tabular}

In all cases (male, female and combined sex), immature fishes showed more or less high 'Kn' values, which continued to decline gradually as the length increased up to $19-21 \mathrm{~cm}$ in males and $21-23 \mathrm{~cm}$ in females and combined sex (Fig. 3). The peak of ' $\mathrm{Kn}$ ' value was observed in 23-27 cm length class which started from 19-21 cm length in male fish but no decline of 'Kn' value from peak was observed (Fig. 3). The apparent incompleteness of the curve in male $R$.

corsula beyond 23-27 cm length class is probably due to the non-availability of specimens of more than $27 \mathrm{~cm}$ length in the samples. Like other fishes, $R$. corsula showed high 'Kn' values during immature stage (Fig. 3) due to higher rate of feeding and growth during this stage (Qasim 1957, Menon 1950), as they grew 'Kn' value tend to decline gradually (Fig. 3). But before maturity, the metabolic rate might have increased due to pre-spawning fat deposition and gonad development (Gowda et al. 1987), as a result, the weight of fish increased quickly in mature fishes $(19-21 \mathrm{~cm}$ in male and $21-23 \mathrm{~cm}$ in female and combined sex) (Fig. 3) and the highest value of 'Kn' was observed during this 


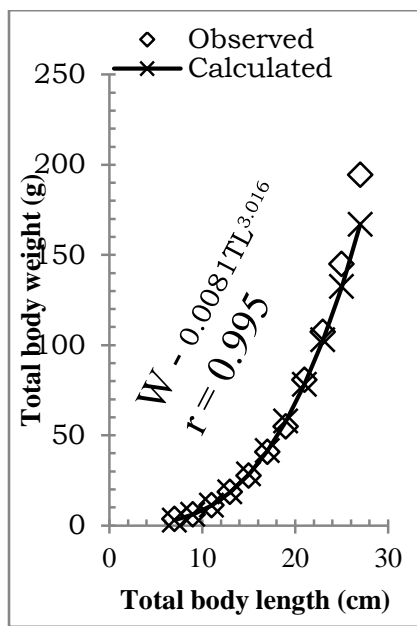

(a)

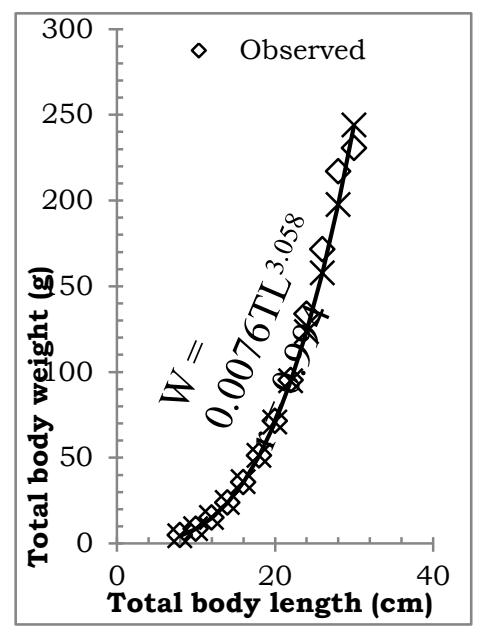

(b)

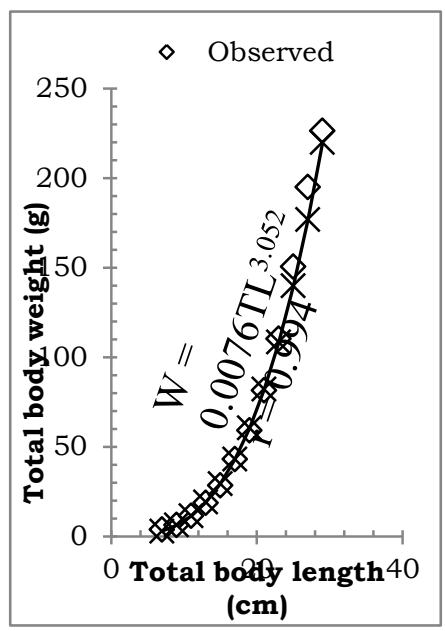

(c)

Fig. 1. Length-weight relationship (arithmetic) of male (a), female (b) and combined sex (c) of $R$. corsula from Sitakunda coast during 2016-18.

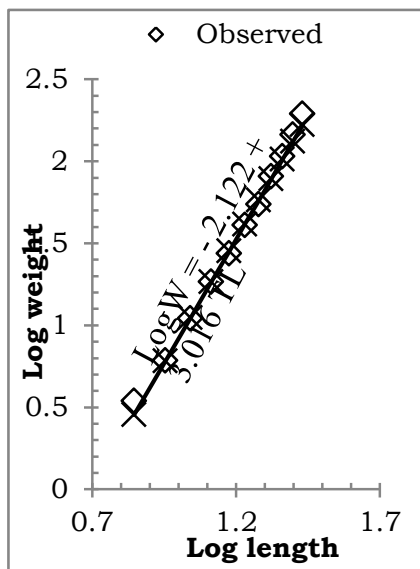

(a)

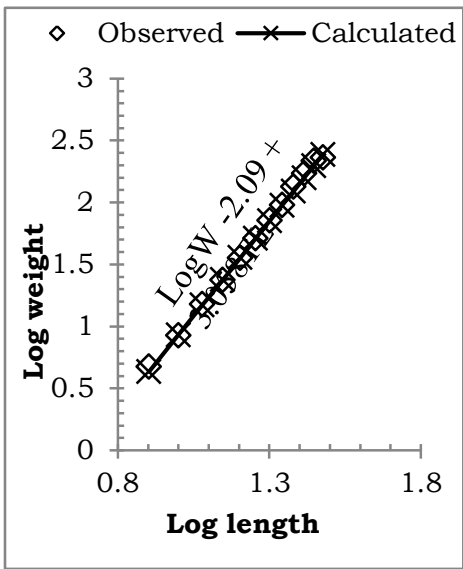

(b)

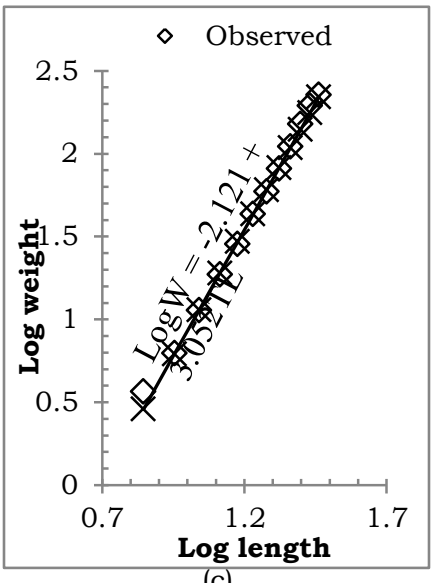

(c)

Fig. 2. Length-weight relationship (logarithmic) of male (a), female (b) and combined sex (c) R. corsula from Sitakunda coast during 2016-18.

stage for both males $(23-27 \mathrm{~cm})$ and females $(25-27 \mathrm{~cm})$ as well as in combined sex (25-27 cm) (Fig. 3). Fatima (1991) found peak in 26.1-28.0 cm and 30.1$32.0 \mathrm{~cm}$ length classes, respectively for male and female $R$. corsula. Monthly fluctuations in the ' $\mathrm{Kn}$ ' values were observed throughout the 24 months of investigation for both male and female as well as in combined sex (Fig. 4). In all cases, annual data of the two consecutive years showed variations, but a more or less generalized trend was followed - raise of 'Kn' values from pre spawning season (June) to spawning season and a gradual decline was observed from late 
spawning season to post spawning season (Fig. 4). For males, the highest peak of ' $\mathrm{Kn}$ ' was recorded in August 2016 and 2017, whereas for the females, the highest peaks were observed in November 2016 and October 2017, respectively during the two years study period that fell in the peak spawning season. The results (Fig. 4) clearly indicated that fluctuation patterns of 'Kn' values are more or less similar in both sex, suggesting almost similar metabolic activity in males

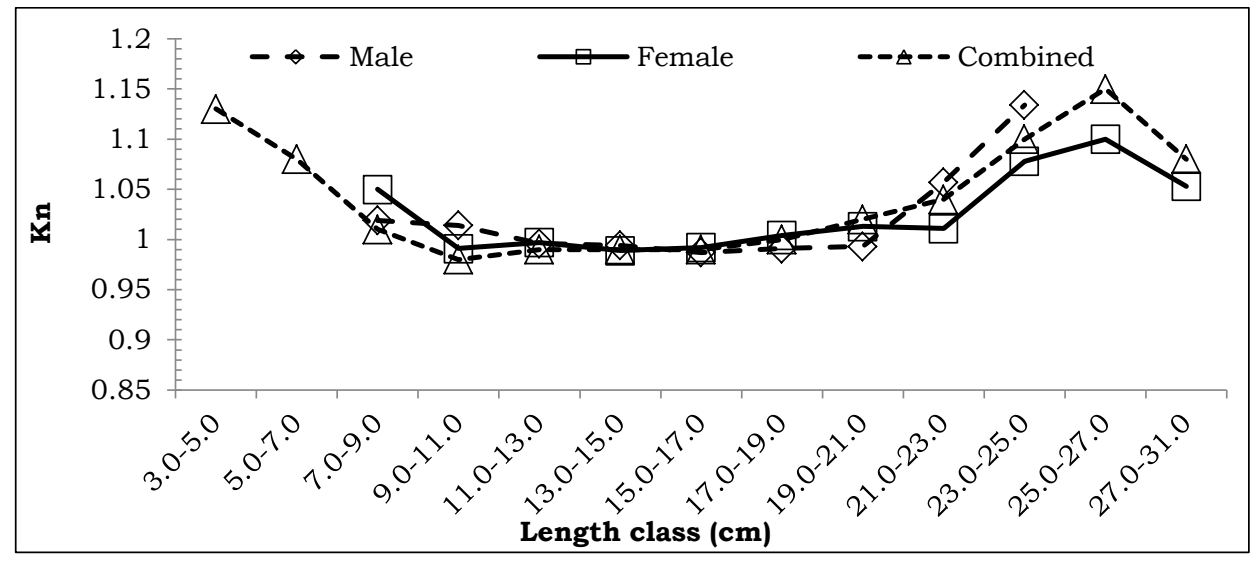

Fig. 3. Relative condition factor (Kn) of different length class of male and female $R$. corsula.

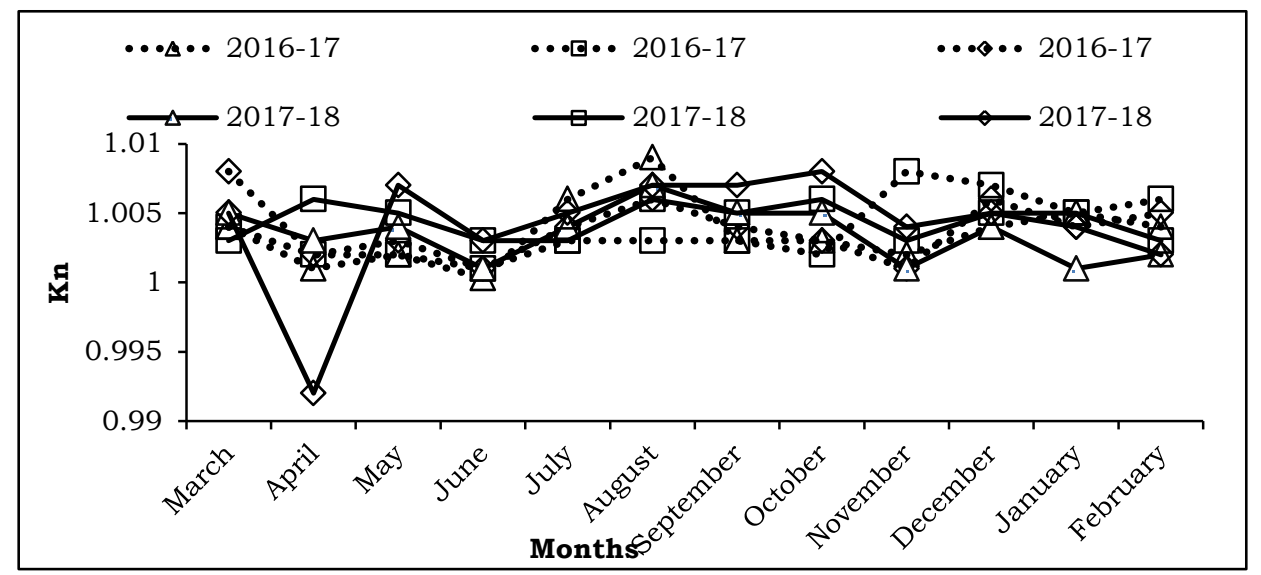

Fig. 4. Monthly variations of relative condition factor of male, female and combined sex of $R$. corsula during 2016-17 and 2017-18.

and females (Fatima 1991). The conspicuous appearance of matured fish between April and August may have given rise to ' $\mathrm{Kn}$ ' values anf extended spawning season might cause the fluctuations condition factor of fish. Findings 
of the present study are in close agreement with the findings of Fatima (1991) in $R$. corsula and Morrow (1951) in Longhorn sculpin, who had reported that the initial peak of the 'Kn' values, which appeared at the beginning of the spawning season might be related to the pre-spawning growth of the gonads. Similar observations have also been made by Pillay (1954), Sarojini (1957), Gowda et al. (1987) for different species of mullets. The study of relative condition factor has been used to compare the pulpiness of fish. It is used to compare the weight of fish against a standard calculated weight to ascertain the condition of fishes compared to the standard condition. As the monthly mean condition factor never went below one (1.0), it can be concluded that the health condition of $R$. corsula collected from the Sitakund coast of the Bay of Bengal was good, indicated a good and healthy condition of the environment.

\section{CONCLUSION}

In fisheries management, information on length-weight relationships for a given species could be used in setting up yield equations (Beverton and Holt 1957, Ricker 1958). In fish yield measurement from a water body and in regulation of fisheries through construction of desirable mesh-size of the fishing gear in response to the market demand for a fish not having less than a marketable size and weight-the knowledge of length-weight relationship for a given species could be of practical utility in fisheries practices (King 2007). The relative condition factor is an important tool for investigating the body condition and the general well-being of a fish (Hossain et al. 2006) in its environment. This may vary with food abundance and the average reproductive stage of the fish stock (King 2007),

and also parasitic infections and physical factors reflecting recent physical and biological circumstances (LeCren 1951).

\section{LITERATURE CITED}

AKTHER, S. and AKTHER, S. 2013. Notes on length-weight relationship and condition factor of Cirrhina reba (Hamilton) (Cyprinidae: Cypriniformes. Univ. J. Zool. Rajshahi Univ.32: 81-83.

ALI, R.A.S., ELAWAD, A.N., KHALIFA, M.M. and EL-MOR, M. 2016. Length-weight relationship and condition factor of Liza ramada from Eastern Coast of Libya. Int. J. Fish. and Aqua. Res. 2(2): $1-9$.

ALLEN, K.R. 1938. Some observation on the biology of the the Trout in Windermere. J. Anim. Ecol. 7: 333-349.

AZADI, M.A. and ULLAH, M. 2008. Length-Weight relationship and condition factor of Ribbon fish Lepturacanthus savala (Cuvier, 1829) from the Bay of Bengal, Bangladesh. Chittagong Univ. J. Biol. Sci. 3(1\&2): 119-126. 
AZADI, M.A. and NASER, A. 1996. Length-weight relationship and relative condition factor of a carp, Labeo bata (Ham.) from Kaptai reservoir, Bangladesh. Chittagong Univ. Stud. Part 2. Sci. 20(1):13-18.

AZADI, M.A. and RAHMAN, A.K.M.S. 2007. Length-weight relationship and relative condition factor of Gonialosa manmania (Ham. 1822) (Clupeidae: Clupeiformes) from Kaptai Lake Bangladesh. Chittagong Univ. J. Biol. Sci. 2(1\&2): 71-80.

AZADI, M.A., ISLAM, M.A. and SOLAIMAN, S. 1988. Length-weight and girth-Weight relationship and relative condition in Eutropiicththys vacha from Kaptai reservoir, BAAS Abstract. Section 2, 63, 27 pp.

AZADI, M.A. and NASIRUDDIN, M. 1990. Some aspects of biology of Oreochromis niloticus (Linn.) from Kaptai lake. Bangladesh J. Sci. Res. Special issue. 59-68.

AZADI, M.A., ISLAM, M.A. and PAUL, J.G. 1992. Biology and Fishery of the Catfish, Mystus aor in the Kaptai Reservoir, Bangladesh. P.125-140. In S.S. De Silva (ed.), Reservoir Fisheries of Asia. International Development Research Center (IDRC), Ottawa, Canada.

AZADI, M.A. and ARSHAD-UL-ALAM, M. 2011. Length-weight relationship and relative condition factor of Gangetic hairfin anchovy, Setipinna phasa (Hamilton) from the River Halda, 18 ${ }^{\text {th }}$ Nat. Conf. \& AGM 2011 of Zoological Society of Bangladesh, Abstract No. 26, p. 36.

BAL, J.W. and JONES, J.W. 1960. On the growth of the brown trout of Llyn Tegid. Proc. Zool. Soc., London.134:1-41.

BEVERTON, R. J. H. and HOLT, S. J. 1957. On the dynamics of exploited fish populations. Fisheries Investigation Series II, Vol. 19. The Blackburn Press, Caldwell, NJ, USA.533 pp.

CARLANDER, K.D. 1977. Handbook of freshwater fishery biology. Vol. II. The Iowa State University Press, Ames. IOWA. 431pp.

ÇELIK, Ö. and TORCU, H. 2000. Investigations on the biology of red mullet (Mullus barbatus Linnaeus, 1758) in Edremit Bay, Aegean Sea, Turkey. Turkish J. Vet. and Anim. Sci.24(3): 287-296.

CHATTERJI, A., SIDDIQUI, A.Q. and KHAN, A.A. 1977. Length-weight relationship of Labeo bata (Ham.). Proc. Indian Acad. Sci. 86 B (3):189-194.

CHU, W.S., HOU, Y.Y., UENG, Y.T. and WANG, J.P. 2012. Length-weight relationship of large scale mullet, Liza macrolepis (Smith, 1846), of the south-western coast of Taiwan. Afric. J. Biotech. 11: $1948-1952$.

DAS, P. 1977. Length-weight relationship and relative condition of grey mullet, Mugil cephalus. Mahasagar 10: 145-149.

DAS, P.R., UDDIN, M.S., ISLAM, M.S., BISWAS, M. and MIA, M.R. 2018. Length-weight relationship and sex ratio of Amblypharyngodon mola in Dekar Haor of Sunamganj Bangladesh. J. Asiat. Soc. Bangladesh (Sci.) 44(2): 185-193.

DOHA, S. and DEWAN, S. 1967. Studies on the biology of Tilapia mossambica (Pters). III. Length- 
weight relationship and condition factor. Pakistan J. Sci. 19: 14-23.

ERGUDEN, D., TURAN, C., and GURLEK, M. 2009. Weight-length relationships for 20 Lessepsian fish species caught by bottom trawl on the coast of Iskenderun Bay (NE Mediterranean Sea, Turkey). J. App. Ichthyol. 25(1): 133-135.

FATIMA, M. 1991. Studies on the biology of a grey mullet, Rhinomugil corsula (Hamilton), collected from River Yamuna. PhD thesis, Department of Zoology, Aligarh Muslim University, Aligarh, India, $198 \mathrm{pp}$.

FATIMA, M. and KHAN, A.A. 1993. Cyclic changes in the gonad of Rhinomugil corsula (Hamilton) from the River Yamuna, India. Asian Fish. Sci.6: 23-29.

FROESE, R. AND PAULY, D. (eds.) 2018. "Squalomugil nasutus" in FishBase. June 2018 version.

GOWDA, G., SHANBHOGUE, S.L., and UDUPA, K.S. 1987. Length-weight relationship and relative condition of grey mullet, Valamugil seheli (Forskal), from Mangalore waters. Indian J. Fish. 34(4): 340-342.

GROVER, J.H. and JULIANO, R.O. 1976. Length-weight relationship of pond-raised milkfish in the Philippines. Aquacultur 7: 339-346.

HILE, R. 1936. Age and growth of the cisco Leucichthys artedi (Le Sueur), in the lakes of the northeastern highlands, Wisconsin. Bull. U.S. Bureau Fish.48: 211-317.

HILE, R. 1948. Standardization of method of expressing length and weight of fish. Trans. Am. Fish. Soc. 75: 157-164.

HOSSAIN, M.Y., AHMED, Z.F., LEUNDA, P.M., JASMINE, S., OSCOZ, J., MIRANDA, R. and OHTOMI, J. 2006. Condition, length-weight and length-length relationships of the Asian striped catfish (Mystus vittatus (Bloch, 1794) (Siluriformes : Bagridae) in the Mathabhanga River, southwestern Bangladesh. J. App. Ichtiol. 25(1): 304-307.

JOHNSON, C.A.K. and NDIMELE, P.E. 2010. Length-Weight Relationships and Condition Factors of Twenty-One Fish Species in Ologe Lagoon, Lagos, Nigeria. Asian J. Agri. Sci. 2(4): 174-179.

KAR, D. and BARBHUIYA, M.H. 2000. Length-weight relationship and condition factor in Gudusia chapara (Ham.-Buch) and Botia dario (Ham.-Buch) from Chatla Haor (flood plain wetland) Cachar District of Assam. Environment and Ecology 18(1): 227-229.

KING, M. 2007. Fisheries biology, assessment and management (2 ${ }^{\text {nd }}$ ed.). Blackwell publishing, Oxford, London, 382 pp.

LECREN, E.D. 1951. The Length-Weight relationship and seasonal cycle in gonad weight and condition in the pearch (Perca fluviatilis). J. Anim. Ecol, Oxford, 20:201-219.

MARTIN, W. R. 1949. The mechanics of environmental control of body form in fishes. Univ. Toronto. Stud. Biol. 58: 1-9.

MAMUN, A. and AZADI, M.A. 2004. Length-weight relationship, relative condition factor and size frequency distribution of Amblypharyngodon mola (Hamilton) inhabiting Kaptai Reservoir, Bangladesh, Progress. Agric. 15(1):173-180. 
MENON, M.D. 1950. Bionomics of the poor cod, Gadus minutas L. in the Plymouth area. J. Mar. Biol. Ass. U.K.29: 185-239.

MORROW JR, J.E. 1951. Studies on the marine resources of south New England VIII. The biology of the long horn sculpin, Myxocephalus ostodecimapinosis Mitchell with a discussion of the southern New England 'trash' fishery. Bull. Bingh. Ocean. Coll.13: 1-41.

MORTUZA, M.G. and RAHMAN, T. 2006. Length- weight relationship, condition factor and sex-ratio of freshwater Rhinomugil corsula (Hamilton) (Mugiliformes: Mugilidae) from Rajshahi, Bangladesh. J. Bio. Sci. 14: 139-141.

MOSLEN, M. and MIEBAKA, C.A. 2017. Length-weight relationship and condition factor of Mugil cephalus and Oreochromis niloticus from a Tidal creek in the Niger Delta, Nigeria. Arch. Agri. and Environ. Sci. 2(4): 287-292.

PARVIN, M.R., FAHAD A.A. and MORTUZA, M.G. 2011. The fecundity and sex ratio of Labeo boga (Hamilton) (Cypriniformes: Cyprinidae) of Rajshahi, Bangladesh. Continental J. Fish. \& Aqua. Sci. 5(3): 19-21.

PILLAY, T.V.R. 1954. The biology of the grey mullet, Mugil tade, Forskal, with notes on its fishery in Bengal. Proc. Nat. Inst. Sci. India.20: 187-217.

PRAMANICK, M.M.H., HASAN, M.M., BISSHAS, S., HOSSAIN, A.B.M.A. and BISWAS, T.K. 2017. Fish biodiversity and their present conservation status in the Meghna River of Bangladesh. Int. $J$ Fish. \& Aqua. Stud. 5(1): 446-455.

QASIM, S.Z. 1957. The biology of Blennius pholis L. (Teleostei). Proc. Zool. Soc. London128: 161-208.

RAJA, A.V. 1967. Length-weight relationship in the oil sardine (Sardinella longiceps). Indian J. Fish.14: 159-170.

RANGANATHAN, V. and NATARAJAN, V. 1969. Studies on the occurance and biology of Rhinomugil corsula in Krishnagiri and Sathanur Reserviors Tamil Nadu, India. J Bomby. Nat. Hist. Soc. 66: 519-532.

RENJINI, P.K. and NANDAN, B.S. 2011. Length-weight relationship, condition factor and morphometry of gold spot mullet Liza parsia (Hamilton, 1822) from Cochin estuary. Indian J. Geo-marine Sci. 40(4): 567-571.

RICKER, W.E. 1958. Handbook of computations for biological statistics of fish populations. Fish. Res. Board Can., Bull.119: 1-300.

RICKER, W.E. 1975. Computation and interpretation of biological statistics of fish populations. Bull. Fish. Res. Board Can. 191:1-382.

ROUSENFELL, G.A. and EVERHART, W.H. 1953. Fishery Science. The Method and Application. Jhon Wiley and sons, New York.

SAROJINI, K.K. 1957. Biology and fisheries of the grey mullets of Bengal. I. Biology of Mugil parsia Hamilton with notes on its fishery in Bengal. Indian J. Fish. 4(1): 160-207.

SHAFI, M. and QUDDUS, M.M.A. 1975a. The length-weight and length-grith relationship and 
condition factor in the carp, Labeo calbasu. Dacca Univ. stud. Pt. B. XXIII(1): 45-49.

SHAFI, M. and QUDDUS, M.M.A. 1975b. The length-weight and length-grith relationship and condition factor in the carp, Labeo rohita (Hamilton, 1812). Bangladesh J. Sci. Ind. Res. $\mathbf{x}$ (3\&4): 268-273.

SHARMA, P.K. 2015. Length-weight relationship and relative condition factor of gangetic hairfin anchovy Setipinna phasa (Hamilton, 1822) in Dhubri district of Assam, India. Adv. Appl. Sci. Res. 6(1): 5-10.

SPSS 16.0 BreifGuide 2007. SPSS Inc. 233 South Wacker Drive, 11th Floor. Chicago, IL 606066412. PP. 551.

SUGANAN, V. V. and VINCI, G. K. 1981. Length-weight relationship and food feeding study of Rhinomugil corsula (Hamilton) with a note on its spawning and fecundity from Nagarjunasagar Reservior A. P., India. J. Inland Fish. Soc. India 13(1): 25-35.

TÜRKER, D. and BAL, H. 2018. Length-Weight Relationship and Condition Factor of Red Mullet (Mullus barbatus barbatus Linnaeus, 1758) from the Western Black Sea, Turkey. Natural and Engineering Sciences 3(2): 120-127.

ZUBIA, M., REHANA, Y., MUHAMMAD, S.H., OMER, M.T., LAKHT-E-ZEHRA, and ADEYEMI, S.O. 2014. Length-weight relationship, condition and relative condition factor of four Mugilid species (Family Mugilidae) from the Karachi Coast of Pakistan. J. Coast. Dev. 17(385): 1-6.

(Manuscript received on 26 October, 2020 revised on 18 November, 2020) 